Dorota Nowalska-Kapuścik

ORCID: 0000-0003-4224-3257

University of Silesia, Poland ${ }^{1}$

\title{
How do senior citizens cope with energy poverty? Evidence from a local case study in the Polish Silesia region
}

\begin{abstract}
The subject of this article is energy poverty understood as having difficulties with satisfying the basic energy needs in the household. The main goal of the article is to find the patterns and strategies used by the Polish senior citizens dealing with the effects of fuel poverty and to recognize how this type of poverty affects the life of individuals, their families and local environment. This is done using original data from a case study conducted by the author in Lipiny, Swiętochłowice municipality, which is an example of post-industrial area of Silesian province in Poland. The study comprised 30 individual interviews with elderly members of households affected by the problem of fuel poverty. The results show complex relations between fuel poverty and (non)fulfilment of various needs by the elderly. The findings suggest the necessity of local authorities' systematic action focused on prevention of fuel poverty in local communities.
\end{abstract}

Key words: energy poverty, fuel poverty, elderly people, local social policy

1 Correspondence: Wydział Nauk Społecznych/Instytut Socjologii, Uniwersytet Śląski, ul. Bankowa 12, 40-007 Katowice, Polska; author's email address: dorota@constel.pl 
Introduction

Energy poverty currently affects a significant number of European households, representing a growing problem in the European Union. The phenomenon is relevant to the European governance and policy strategy at different levels, having social, economic, political, environmental and health implications (Papada \& Kaliampakos, 2018, pp. 153-164). Energy poverty is most often seen in economic terms and in terms of practical measures aimed at counteracting it. Meanwhile, energy poverty issues are complex and multidimensional, combining different aspects of economy, politics, society, and culture. Despite the growing number of people affected by or threatened with energy poverty this issue is not a popular subject of political discussions or executed projects. In Poland, studies on this issue have been conducted on the national level (Frankowski, 2020; Liset et al., 2015; Miazga \& Owczarek, 2015; Rutkowski et al., 2018; Węglarz et al., 2014); however, only few of these studies refer to a local scale (Pyka et al., 2014). Therefore, not only are there gaps in our knowledge on this topic, but also - what seems to be particularly important - there is no perception of energy poverty as a significant social problem, especially in the context of socially sensitive groups.

Having identified this research gap, the goal of this article is the analysis of intensity and severity of energy poverty and assessment of the level of threatening with the aspects of poverty among the elderly in a regional system. The article is meant to find the patterns and strategies of Polish senior citizens dealing with the effects of fuel poverty and to recognize how this type of poverty affects the life of individuals, their families and local environment. This is done using the original data from a case study conducted by the author in Lipiny, Świętochłowice municipality, which is an example of a post-industrial area of Silesian province in Poland.

\section{Defining and measuring energy poverty}

A definition of energy poverty assumes that that to maintain a sufficient level of heating, that is, temperature of at least $21^{\circ} \mathrm{C}$ in the main rooms and $18^{\circ} \mathrm{C}$ in the remaining rooms, a household affected by energy poverty must use more than $10 \%$ of its income (The UK Fuel Poverty Strategy, 2008, p. 40). A standard rate of energy poverty was also accepted that uses a ratio of fuel costs understood as a product of fuel consumption and its price, and income of a household. In the event that the value of rate is higher than $10 \%$, then a household is treated as affected by energy poverty (The UK Fuel Poverty Strategy, 2008).

In response to the growing threat of energy poverty, analysed from a global perspective, the European Fuel Poverty and Energy Efficiency Project (EPEE) ${ }^{2}$ was established, financed by the European Commission. Its fundamental goal is knowledge acquisition

2 European Fuel Poverty and Energy Efficiency — a project focused on recognition and prevention of income poverty executed by the European countries: France, Belgium, Spain, Great Britain, and Italy. Detailed data: www.ec.europa.eu/energy/intelligent/index_en; www.fuel-poverty.com. 
and understanding the essence of fuel poverty. Detailed actions oscillate around the following issues: adopting a common definition of energy poverty (for EU countries), determining the basic rates necessary to measure it, analysing fuel poverty in specific countries, as well as assessing the effectiveness of combatting it. The work of EPEE have resulted in determining a starting definition of energy poverty, that is: "not being able to maintain heating at the sufficient level for a fair price" (EPEE, 2009). The so-called socially sensitive groups (people having low income, covered by social assistance, indebted, working part-time, disabled, and single parents and the elderly) were also defined.

In accordance with the estimations presented in the European Fuel Poverty and Energy Efficiency publication (EPEE, 2009), between 50 and 125 million inhabitants in Europe are affected by fuel poverty. It is expected that this number will be systematically growing. Such assumption based on close relation occurring between fuel poverty and prices of - not only - energy: the more expensive the energy and the higher its consumption and lower income, the higher the risk of energy poverty. The following factors also contribute to its increase: poor thermal insulation and inefficient and ineffective heating system, poor technical condition of the building (Frankowski, 2020; Aron et al., 2013; Miazga \& Owczarek, 2015). These factors make it harder to keep the appropriate temperature at home $\left(21^{\circ} \mathrm{C}\right)$, and also have a negative impact on energy consumption, generating additional costs.

The satisfaction of basic energy needs is treated as a fundamental element of social security systems and is a subject of public policies in developed countries. EU member states are obliged to apply national plans on energy and climate and to shape long-term strategies. Implemented requirement of allotting the part of financial resources to combat fuel poverty through renovations of low-income households has not prevented the process of growing inequalities in the European countries. A high diversity in fuel poverty is an effect of differences in the level of urbanization, structure of buildings, climate and income and type of households. This problem particularly affects the countries of Central and Eastern Europe where - as it was shown by Wendel Trio: ${ }^{3}$ "the leaders of specific countries must immediately start creating national policies and means of protection for the most sensitive households and combine these policies with resources concerning energy efficiency, renewable energy, renovations of buildings and protection of sensitive consumers" (CAN, LIFE Unify, 2020). General conclusions resulting from data analysis are not satisfactory. It may be said that none of the analysed countries can combat fuel poverty, and their results are far from the basic EU minimum (CAN, LIFE Unify, 2020).

Due to the global scale of energy poverty, the improvement of energy efficiency and actions preventing energy exclusion should focus on provision of conditions for development of infrastructural interregional and international connections and coordination within

3 Wendel Trio is the director of CAN: Climate Action Network (CAN) Europe, Europe's leading NGO coalition fighting dangerous climate change. With over 170 member organisations active in 38 European countries, representing over 1.500 NGOs and more than 47 million citizens, CAN Europe promotes sustainable climate, energy, and development policies throughout Europe: https:// caneurope.org/about-us/\#learn-about-us (access 8.02.2021). 
undertaken initiatives. Currently, the responsibility for energy policy has been left to the local governments; the lack of synergy between executed actions makes it more difficult to develop effective tools of supporting people affected by energy poverty. As a consequence, energy projects implemented in specific countries (coking plants, clean coal, renewable energy) give hope for the expected technological effects in the future, however, they are not a response to basic challenges of the communities focusing on (difficult) current situation. In order to improve the flow of information and exchange of good practices, the EU Energy Poverty Observatory (EPOV) has been established. It is an initiative of the European Commission to support member states in their efforts to alleviate energy poverty. Although reports developed by EPOV (EPOV, 2020) provide access to data illustrating the scale and scope of the problem in selected countries, due to the fact that EPOV is part of the European Commission's policy efforts - these data obviously refer to EU countries only.

\section{The problem of energy poverty in Central and Eastern European Countries: overview}

As far as Central and Eastern European countries are concerned, the rates of energy poverty are available for Bulgaria, Czech Republic, Croatia, Estonia, Hungary, Lithuania, Latvia, Romania, Slovakia, and Slovenia. Relatively better situation is in the Czech Republic, which has a higher rate than the EU average of the population-reported indicators. According to the report (EPOV, 2020), 2.7\% of Czech citizens reported that they were unable to maintain the right temperature in their homes, while the corresponding EU average is $7.3 \%$. Data from Slovenia (3.3\%), Slovakia (4.8\%) and Hungary are also positive. In 2018, $6.1 \%$ of the Hungarian population reported that they were unable to keep the home adequately warm (7.3\% in the EU). The situation in Estonia is slightly worse. In 2018, $6.5 \%$ of Estonians reported that they are behind with of utility bills payment. The fraction of the Estonian population that stated that they are unable to keep their home warm is only about a third of the EU average (EPOV, 2020).

When analysing the situation in the Central and Eastern European Countries, although statistical data demonstrate the scale of the problem, information about the implemented (or not implemented) preventive and corrective actions are similarly important. The strategies of preventing fuel poverty have been applied since a few years in Romania. Romania has a higher rate on the population-reported indicators than the EU average (9.6\%), however it makes concerted efforts in improving and renovating existing building stock via programmes partly funded by the European Union. On the other hand, there are no similar actions in Latvia, where no detailed research on fuel poverty has been conducted yet. This fact is particularly alarming in the context of data: in 2018, $7.5 \%$ of Latvians reported that they were unable to keep their home adequately warm, while the corresponding EU average is slightly lower, at 7.3\%. The high energy expenditure is likely to put a strain on the household budget and might indicate a poor energy efficiency of the building. A slightly higher rate $\mathbf{( 7 . 7 \% )}$ ) was observed in Croatia. It should be emphasized that the percentage of people who are not able to keep the right temperature in their 
households has been decreasing since 2017. The decrease in these rates, particularly of the arrears on utility bills, may be caused by the number of social support schemes within the scope of electricity, gas and household costs introduced by the national government (EPOV, 2020).

The countries with the biggest problem with maintaining right temperature in the flats is Bulgaria. In 2018, 33.7\% of Bulgarians reported that they were unable to keep their home adequately warm while the corresponding EU average is $7.3 \%$. Similarly for $2018,30.1 \%$ of the population was unable to pay their utility bills on time due to financial difficulties, while the respective EU average is 6.6\% (EPOV, 2020). The data concerning households that are behind with payment of utilities bills and other bills are also negative (from $19 \%$ in 2005 to $30 \%$ in 2018). The rate on the inability to keep the home adequately warm is particularly high in Lithuania. In 2018, $27.9 \%$ of people reported that they were unable to keep their homes adequately warm (EPOV, 2020). However, it should be emphasized that in comparison with 2005, this number is systematically decreasing. It is an effect of the drop in energy prices and general wage increase in Lithuania, which results in a higher standard of living.

Generally, it may be assumed that the problem of fuel poverty in the countries of Eastern-Central Europe is characterized by a high diversity both in terms of the scale of the problem and methods applied to prevent this phenomenon from spreading. The biggest difficulties arise for people whose financial conditions can be regarded as modest (or very modest), living in buildings of low energy standards who in the context of growth of energy prices, are not able to pay energy bills. People running a single-person households, large families and the elderly are the most exposed to the consequences of the problem of fuel poverty (Pollard et al., 2019).

Apart from typical factors generating fuel poverty, climatic conditions also have an impact. Interestingly, the problem with keeping right temperature in the habitats is strongly emphasized not necessarily in places with temperate and cold climate, but also in the countries of warm, mild climate. One may suppose that with a short-term (transitional) period of low temperatures, both people and buildings are not adapted to worse weather conditions, thinking that there is no need to invest in better insulation or proper heating system. There is also insufficient knowledge of the negative impact of fuel poverty on health and the general quality of life standard.

\section{Energy poverty in Poland}

In Poland, fuel poverty is not treated as a separate issue, but as an area of preventing poverty and social exclusion. The lack of coordinated research on this problem is partly an effect of the lack of definition both the one including the phenomenon of fuel poverty, and the one determining the scope of understanding the so-called socially sensitive consumers. The research conducted for the purposes of $\mathrm{URE}^{4}$ were focused on the analyses of the

\footnotetext{
4 The Energy Regulatory Office (Poland).
} 
impact of an increase in energy prices on impoverishment of the households. Apart from showing simple, sometimes surprising relations (a growth of energy prices by $10 \%$ leads to 1,010,000 energetically poor households); there are no data allowing to draw appropriate conclusions about causes and ways of connecting the growth of prices of energy and gas with impoverishment of the households (Kurowski, 2008). In 2017, 10\% of households in Poland suffered from energy poverty (...) About half of these households were also income-poor. In population terms, this means that 3.35 million people out of the 38 million people living in Poland (8.8\%) are somehow affected by energy poverty (CAN, LIFE Unify, 2020).

Fuel poverty in Poland (Sokołowski et al., 2019) is a complex, multifaceted problem that includes sociological, psychological, and political aspects. It is assumed (Bouzarovski \& Petrova, 2013), that fuel poverty is a situation in which the household has no access toa level of energy services matching its social and financial necessities. Fuel poverty means problems with satisfying one's basic fuel needs, which leads to discomfort caused by inability to have an appropriate - according to one's needs - temperature in the rooms. As a consequence, the majority of energy poor people is affected by many negative health effects such as respiratory diseases, cardiovascular diseases, hormonal disorders, as well as anxiety disorder and depression. Looking for effective methods of dealing with energy problems leads mainly to implementation of one of two strategies. The first strategy is based on the attempt of radical energy saving, whereas the second strategy reduces expenses on other consumer needs to have enough money to pay the energy bills. In the long term, both approaches lead to deficits in access to specific goods and services.

"As yet, no consensus has emerged for measuring and monitoring fuel poverty and explaining why and how it differs from income poverty" (Khandker, 2013), which results in constant controversies concerning the perception of economic poverty as tantamount (synonymous) to fuel poverty. Whereas "the association between expenditure poverty and energy poverty depends on the level of access to modern energy sources and the efficient use of traditional ones" (Khandker, 2013), but also on the size of a household, climatic and environmental context, patterns of consumer behaviours, habits and individual preferences of inhabitants. The aspect of energy awareness and knowledge of effective ways of using electric energy is also significant here, which may determine energy consumption in the flats and houses. This factor, apart from low income of the households, high costs of energy and bad technical condition of residential buildings and available heating systems, is treated as the most significant cause of fuel poverty.

The groups of people particularly exposed to fuel poverty are households with single parents, large or extended families, farmers and villagers, people living in single-family houses or large houses, as well as the elderly. It should be added that vulnerable consumers in Poland are low-income people, whose buildings and devices are characterized by low energy efficiency and who ineffectively use energy and devices in their households (Rutkowski et al., 2018). The fact that their households are often characterized by extremely poor technical condition of the buildings and heating systems is particularly worrying. 
Meanwhile, in Poland, energy poverty relates mostly to the heating in dwellings (CAN LIFE Unify, 2020). It is believed (IBS, 2018) that single-family buildings (row houses or semi-detached houses) and old multi-family buildings are most at risk of fuel poverty. Housing conditions in Poland (GUS, 2020) are improving in comparison with the previous years. Recently, there were investments in sanitary and technical infrastructure, increasing the length of water and sewage system and connections. When it comes to electricity consumption in total by the households in Poland, it increased slightly in 2019 to about $30613.2 \mathrm{GWh}$, whereas electricity consumption per consumer in the households decreased to $1963.9 \mathrm{kWh}$. Gas consumption (up to $47855.3 \mathrm{GWh}$ ) also increased and the number of consumers increased by $1.9 \%$ ).

The average size of the dwelling rose by 0.9 sq. $\mathrm{m}$ to $74.0 \mathrm{sq} . \mathrm{m}$, the average floor space of the dwelling per person increased by 1.5 sq. $\mathrm{m}$ (reached 27.8 sq. m). Dwellings in rural areas were 28.9 sq. $\mathrm{m}$ higher than in urban ones but was more densely populated than in the cities. The share of dwellings fitted with technical and sanitary facilities increased, however, the network gas was available in only every second apartment. The number of flats equipped with gas increased by $3.3 \%$, with greater growth in rural than in urban areas (GUS, 2018).

Despite improvement of housing conditions, a large percentage of inhabitants of large and very large cities live in multi-family buildings (estates with large panel buildings), and in the tenement houses (24\%). These buildings are mostly old: one-fifth of them were built in the 1970s, $16 \%$ were built in the 1980 s and $14 \%$ in the $1960 \mathrm{~s}$. The number of single-family houses (row houses, semi-detached houses) is systematically increasing. In Poland, both single-family adult-family buildings are at high risk of fuel poverty. More than $80 \%$ of all people affected by fuel poverty live single-family houses. The combination of relatively large residential space with lower energy efficiency creates the real risk of problems with meeting energy needs. When it comes to multi-family buildings, there is a strong correlation between the age of a building and the degree of fuel poverty risk. This risk is increasing with the age of a building. According to the research (IBS, 2018), the inhabitants of pre-war tenement houses are $40 \%$ of all people affected by fuel poverty among inhabitants of multi-family buildings.

In Poland, there is a high regional diversity of the level of fuel poverty, which is an effect of a few factors: 1) household specificity; 2) prices of energy carriers; 3) the age of a building. When analysing data concerning distribution of fuel poverty in specific regions of Poland, we must remember that it is not always a province of the largest percentage of the households affected by fuel poverty that has the largest number of the households affected by fuel poverty. It results from large differences in population count and density in specific provinces. This rule also works the other way round. In the Silesian province, although the percentage of single-family houses affected by fuel poverty is the lowest in Poland, $8.6 \%$ (for example, the percentage exceeds $18 \%$ in the Opole province), the number of single-family houses affected by fuel poverty is two times higher in comparison with the Opole province (IBS, 2/2018). An analysis concerning people living in multi-family houses affected by fuel poverty also gives negative results. In the 
Silesian province, $17 \%$ of people affected by fuel poverty lives in the buildings erected in 1956-1960. A higher percentage is observed only in the Lesser Poland province (18\%). It is conditioned by history and related to the process of shaping the settlement structure in a specific region. The Silesian province, affected at the turn of the 19th and 20th century by strong industrialization, has a large number of living quarters for factory workers and their families (familoki), tenement, multi-storey, and multi-tenant houses. These buildings, often built before 1918, are characterized by low standard and redundant, inefficient systems. Therefore, it can be assumed that Silesian province is an example of a region with a high level of exposure to fuel poverty due to housing conditions. The demographic situation in the region is similarly poor. On the national scale, this province is inhabited by the largest number of people of old age (apart from the Mazovian province).

This number is increasing every year, causing a general systematic growth of percentage of people aged 65 and older. In 2015, the percentage amounted to $16.7 \%$, in 2016 - to $17.34 \%$, in 2017 - to $17.96 \%$, and to $26.2 \%$ in 2018 (ROPS, 2019). In 2017, there were 4,533,565 senior citizens, which makes the province a leader in Poland. The population distribution in particular age groups of seniors is the following, however, it must be emphasized that - as in the entire country - the number of people in the oldest age groups will be increasing in the coming years. In comparison with data illustrating situation in remaining provinces, we may suppose that in this region, these values will exceed the national average. Both at the national and regional level, the actions are taken to support the seniors in their subjective and active participation in the social life, also preventing the factors that may contribute to their marginalization or exclusion.

As far as legal acts and a formal approach to the problem is concerned, is the National Programme for Counteracting Poverty and Social Exclusion 2020 is a strategic document. The New Dimension of Active Integration (KPPUiWP 2020). Its main goal is: "reducing the number of people threatened with poverty and social exclusion by 1.5 million people and increasing social cohesion". The issue of poverty was included in the social legislation regulations, in which poverty was regarded as one of the elements of a catalogue of causes entitling to receive social assistance (Dz.U. [Journal of Laws] 2017, item 1769). In Silesian province, the Strategy of Development of Silesian Province Ślaskie 2020+ (Strategy, 2013) was selected as a fundamental leading document. Currently, an update of the Strategy Strategia Rozwoju Województwa Śląskiego „Śląskie” 2030 are in progress ${ }^{5}$.

It is assumed (Liddell \& Guiney, 2015; Middlemiss \& Gillard, 2015; Papada, Kaliampakos, 2018; Schleich, 2019) that housing conditions, growing energy and heating bills, as well as low income are the main reasons causing problems with satisfying basic energy needs in a dwelling. The elderly living in old buildings of low energy standards are particularly exposed to fuel poverty, which has impact on higher energy consumption. The lack of sufficient income makes it impossible to cover the costs. An average retirement pension in Poland is about EUR 474 for men and EUR 358 for women (EUROSTAT 2018). The low amounts of retirement benefits, limited access to medical care, as well as

5 https://rcas.slaskie.pl/ 
high living costs make the living standard of a Polish pensioner the lowest in the whole European Union (UN, 2018).

The consequences of fuel poverty go beyond financial aspects of human life and affect mental and physical health (Kuhar, 2020). Mental consequences include, above all, a limited sense of security perceived as a state of being free from threats, from privation in various dimensions of life, as well as having the basic conditions of human life satisfied. When it comes to consequences for physical health, the spectrum of negative effects is broad.

Older people are more prone to health conditions, and spend more time in their homes thus requiring more heating, and energy inefficient houses are linked to increased rates of winter respiratory disease, which can prove fatal to senior citizens (Thomson et al., 2017). A study (Office for National Statistics, 2018) showed excess winter mortality continued to be highest in females and people aged 85 and over, and $34.7 \%$ of all excess winter deaths were caused by respiratory diseases.

\section{Case study and research methods}

In scientific literature, fuel poverty is usually treated in economic categories, focusing actions on practical solutions and measures aiming at prevention of this problem (Staniszewska, 2018; Boguszewski \& Herudziński, 2018). However, the issue of fuel poverty is starting to be complex and multidimensional in nature, combining economic, political, social and cultural aspects, especially with reference to socially sensitive groups.

The main research question in the conducted study was focused on whether the elderly (one of socially sensitive groups) struggle with the problem of fuel poverty and whether there are relations between fuel poverty and satisfying the most important consumer needs.

The goal of the study was to answer following research questions:

1) what are the main causes of fuel poverty?

2) what is the impact of fuel problems on life of inhabitants of the households?

3) do local authorities take actions aiming at preventing and combating fuel poverty?

4) does fuel poverty have an impact on the inhabitants 'health?

Qualitative research was conducted in the form individual in-depth interviews. The process of creating an interview script based on initial theoretical assumptions and analysis of research on fuel poverty.

The research on fuel poverty among people aged 60 and more (Walker, 2004, p. 9) ${ }^{6}$ were conducted between March and June 2019 on a group of 30 interviewees using snowball sampling. The criterion of sample selection were age and income ${ }^{7}$. It needs to be emphasized that a subjective measure of fuel poverty was applied, which means that the research was based on the declarations of the interviewees about the level of

\footnotetext{
6 In accordance with classification "senior citizens are people aged 60 and more."

7 The respondents' financial standing was assessed subjectively by them; legally accepted income criteria were not applied here.
} 
satisfaction of energy needs (or problems with such satisfaction). The interviewees used various forms of support of the Social Welfare Centre in Świętochłowice; however, the fact of being a beneficiary was not treated as an indispensable condition of including a specific individual in the research group. This assumption corresponds to the positions of the Institute of Structural Research (Sałach \& Lewandowski, 2018, p. 4), which stated that it is possible to experience fuel poverty even when a specific household is not treated as poor. It leads to a conclusion that: "fuel poverty should not be perceived as an aspect of income poverty, but as a separate dimension of deprivation" (Sałach \& Lewandowski, 2018, p. 4). A method used during the study was individual interviews conducted during the researchers' vitiate interviewees' homes, or, when the interviewees refused to conduct an interview at home, in the Koło Lipiny Senior Club. The interviews were conducted based on the accepted instructions, arranged into subject sections corresponding to detailed questions.

Finally, 21 women and 9 men representing 30 households took part in the research (it was assumed that people who lived in common households would not take part in the research).

Age range of the interviewees was the following:

- 60-70 years old - 10 women and seven men

- 71-80 years old — seven women and two men

- More than 80 years old - three women

- One person (a woman) has not given her age.

Most people had basic vocational (13) and primary education (9). Five people had secondary education, three - higher education. The households were predominantly twoperson (17) and single-person (8). Five people lived in multigenerational households. The interviewees lived mainly in the tenements (26), four in single-family houses.

The duration of interviews was between one and two hours. All interviews were recorded with the use of a voice recorder — upon the respondents' consent - and after their transcription, their contents were analysed.

The research was conducted in one of the districts of Świętochłowice, situated in north-western part of the city. Lipiny, established in the 18th century, had its period of greatness in the 19th century, using the growing demand for the heavy industry products. Coal and zinc deposits resulted in intensive socio-economic development, creating modern town that, growing along main street, was filled with residential, industrial, and public buildings. It created good conditions for population settling here. The depletion of natural resources, economic crisis, as well as political transformation that took place in Poland after 1989 have initiated a process of economic, ecological, and social degradation of Lipiny, transforming it into a district (not quite rightly) perceived as a poverty enclave (Wódz \& Szpoczek-Sało, 2016). At present, the district is inhabited by about 8000 people (Świętochłowice-Lipiny online). Based on data Diagnoza Problemów Społecznych 2014, Development Strategy of Świętochłowice), we assumed that it is a demographically young district, although the percentage of the elderly has recently increased (more than $10 \%$ of the district's total population). Growing socio-economic and spatial degradation of the 
district corresponds to many social problems, including poverty, long-term unemployment, depopulation, alcoholism and lack of prospects for young people. Industrial heritage of the district results in the decrease of public safety, low economic activity, social exclusion, and poverty. As a consequence, Lipiny is currently a crisis area of the highest (in the scale of the city) number of beneficiaries; in the majority, the income of people using institutional support is below the income criterion (both for single people and those sharing a household). An analysis of residential tissue of the district is particularly alarming; most of the flats are situated in old, devastated buildings that do not comply with hygienic and functional standards. Poor thermal insulation and efficient and effective heating system, as well as relatively low income of the inhabitants justify the selection of Lipiny as a place particularly threatened with fuel poverty.

\section{Case study results}

The starting point for discussion on potential fuel poverty was an attempt to assess financial situation of the respondents. The HC-LI (High Costs - Low Income) (Sałach \& Lewandowski, 2018, p. 3) rate was regarded as the key one, which means that occurrence of fuel poverty is a derivative of two factors: hypothetically high energy expenses and low income. Low income is usually determined through selection of $30 \%$ of people with the lowest income and taking individual income threshold into consideration. We must remember that the researchers did not have the data on the respondents income; subjective declarations by the respondents themselves were a basis for recognizing individuals as people having low income.

\section{Financial standing}

Most of the seniors assessed their economic situation as difficult or very difficult, however, there were rarely objective rates in the statements about financial condition. The interviewees avoided saying about specific amounts, choosing rather general expressions illustrating their financial situation:

"It's bad. I have no choice and must manage somehow, but it's hard, very hard" (K/3) Another respondent added that: "I live on a shoestring (...) generally, it's hard, hard (...)" $(\mathrm{K} / 2)$ For some people, it was an awkward, inconvenient subject, causing is discomfort: "What can I say to you (...)...We have to live and that's it!" (M/4). Experiencing poverty is perceived in the categories of failures, admitting to their limitations, therefore, some people tried to ignore their situation. It seems that the way of dealing with this problem is finding help in a local community, creating a sense of solidarity, community united in the fight to deal with financial crisis: "We all here are in the same boat" $(\mathrm{K} / 18)$. Other interviewees expressed their view in a similar way: "All the people here have similar problems, someone is old and sick and has no choice" (K/3). Only in some cases, a summary 
of one's own financial capabilities created a sense of relative stability, however, as it was emphasized by the interviewees, it was rather an effect of economy than owning sufficient capital. The interviewees said explicitly that: "Life goes on, I don't spend a lot of money, I don't need to buy too much" (K/20).

\section{"Fighting hard to keep it"}

Financial problems are intrinsically connected with the necessity to redefine current patterns of consumption and development of new consumer trends. A low income triggers specific consequences and results in creating a strategy to deal with the problems, including making choices between indispensable expenses and expenses that can be made when sufficient financial resources appear. I was interested in the management of small budget and how the interviewees try to prioritise a pyramid of their needs. Therefore, we asked what they have enough money for, and what is in the area of expenses that "can wait". There are two groups of products in the expenses for basic necessities: the first one related to paying the residential bills (utilities, rent, renting costs etc.); the second one oscillates around medical articles and drugs. It seems that despite their financial problems, the interviewees, treat monthly bills as a priority: "Bills, above all (...), first I have to pay my bills, and then I know how much money I have left (laughing) (K/2). Other statements were similar: "I would not sleep if I hadn't paid my bills (...), my principle has always been that first the bills, then my needs" (K/5). The sense of responsibility seems to be very strong among senior citizens; not being able to pay the bill stirs up emotions: "It's such a shame for me, but what can I do, I am not always able to pay my bills" (M/1). The conducted analysis allows us to formulate a conclusion that potential/real problems with timely payment of bills makes our respondents anxious. They were afraid that the unpaid bills and troubles connected with their collection would be growing: "I have to pay all the bills (...), sometimes I am not able to do it and call immediately (...)" (M/3). According to the interviewees, the energy bills are a significant burden on the household budget. "The prices are going up all the time, especially energy bills (...), the price went up so many times this year" (M/1). The right to change electricity supplier introduced in 2007 was supposed to help consumers calculate costs and select the best offer. Unfortunately, an inefficient customer protection system, the government administration passivity and lack of cooperation between state authorities did not only not contributed to a potential reduction of bills, but also has caused a new threat: the dishonest sellers who use aggressive marketing methods. The credulous and uncritical attitude of the elderly to advertising forms makes them an "easy target". The interviewees emphasized that they were often persuaded to conclude unprofitable new agreements: "They were calling me all the time (...), assuring my bills will be lower, that it would be better for me. I was happy that I would buy something cheaper" $(\mathrm{K} / 3)$ Therefore, it can be assumed that some sellers exploited ignorance of the regulations, health conditions or gullibility of the senior citizens. 


\section{Cutting costs}

Therefore, I was wondering whether senior citizen apply methods to reduce costs. Due to the correlation between technical condition of the buildings/houses and energy expenses, we raised an issue of our respondents' housing conditions. The residential tissue of Lipiny includes, above all, old or very old buildings with numerous structural defects, unheated, squalid. Asked to describe their own residential space, the interviewees emphasized various problems usually connected with the technical condition of their flats, indicating also that administration often leaves them without necessary support, burdening them with costs that - according to the interviewees - should be incurred by the administrators/owners. The senior citizens have no financial resources that would enable them to doat least the basic works: "Everything is falling apart (...), the plaster is coming off, unsealed windows, dampness inside, but I don't have the money to repair it myself" (M/6). One of the interviewees said that she tried a few times to enforce renovation, but with no positive result: "I have mould on the walls, what can I say! Nobody cares about an old lady" $(\mathrm{K} / 18)$. The situation is not better in the event of people who are owners of their flats or houses. An owner of a single-family house said that: "maybe it's great but I have to renovate my house myself (...), I have an old stove that must be heated up in the morning, otherwise it is so cold here and firewood is expensive" $(\mathrm{K} / 3)$. Harsh living conditions and the increase in energy prices force the senior citizens to look for at least temporary methods of dealing with their problems. What seems to enjoy popularity among interviewees is energy saving, however one must stress that in most cases, it simply means to stop using certain devices normally. The respondents try to replace their devices (a washing machine or a fridge) with devices having better energy class only sporadically, because they can't afford to replace the old, still working devices. There is still no awareness that developing set of good practices may result in lower bills. The seniors are sceptical about the possibility of actual improvement within this scope: "But when would it pay for itself? Within 10 years? I don't know if I will live until then!" (M/3). Asked whether they make use of support programs, special energy discounts for senior citizens, they shrug their shoulders or do not believe that participating in such projects can change anything. The attachment to nonrenewable sources of energy and resigning from long-term plans to move towards "green" energy is common here. The senior citizens reluctantly admit what they use to stoke the fire; however, one may have the impression that most of these products are prohibited: "I use everything I can to heat my house (...), it's good that last winters were lighter" (K/3). Although they are careful when they say about themselves, their courage is higher when they say about their neighbours: "We all know that our neighbour uses bottles, cartons, even some plates as a fuel for the stove" (K/21). Under-heating of flats and houses is becoming an everyday problem, in connection with bad technical condition of the buildings and the lack of well-though-out strategy of dealing with this growing issue, we should ask about the impact on health condition of the inhabitants. It is hard to assess the relationship between visible symptoms of fuel poverty with health of the senior citizens, because they do not 
see such connection. The statements show that colds or minor infections may be caused by under heated flats, however, fuel poverty is not treated as a factor for it.

\section{Health conditions}

The process of ageing, although conditioned individually, means escalation of health problems, mobility problems, gradual loss of mental and physical fitness. The actions aiming at senior citizens staying independent, fit and in good condition is a significant burden for the budgets of specific households. The interviewees constantly complain about the increasing prices of drugs and medicaments; they are trying to save money by replacing prescribed drugs with substitutes and resigning from treatment in the privately-owned health centres: "I always ask my doctor about substitutes of my drugs, because the drugs she prescribes are eating away half of my pension" (M/3). "I don't have enough money to buy drugs! I have to pay more than 500 zlotys a month for diabetes drugs. My husband is hypertensive, and it costs a lot. I don't even have to mention other expenses" (K/11).

The necessity to save money for treatment, medical examinations or rehabilitation causes cognitive dissonance among the interviewees: "I know that I have to do it because I have diabetes and hypertension, I have no choice and I have to buy my medicine, but I don't buy any vitamins or drops (...) and then my doctor shouts at me (laughing)" (K/3). Another respondent added that: "I should have rehabilitation because I have a hip problem and I have prostheses (...), it was financed by the National Health Fund (rehabilitation - author's note), but I can't afford private medical care (...). I should, I know I should (...)” (K/2).

\section{Reconstruction of free time}

Low income combined with reliability in payment of bills result in the problems with satisfying different consumer needs. The majority of the interviewees said that they have problems with financing restor the organising their free time: No, no travels, you know I don't go on vacation anywhere. I don't have the money. My children sometimes take me to their home, they live outside the city and have a large garden, but I never go anywhere alone $(\mathrm{K} / 2)$. The respondents indicate the deficit of resources enabling to purchase a trip or organised rest; however, they rather do not feel too much discomfort because of that. One may have the impression that this sphere of consumption is not treated as a basic need. One interviewee said that: I am not young anymore, so I don't go to camps (laughing) (K/1). Rehabilitation spa treatment outside the place of residence compensate vacation trips in some way. The interviewees scrupulously submit applications on time, enjoying this form of rest: I go to sanatorium with my husband (...), when we return, we immediately submit another application $(\mathrm{K} / 20)$. Although the main goal of such trips is treatment of various conditions, the interviewees admit that they also appreciate different aspects of such trips and - as far as possible - try to find centres located in various regions of Poland. 


\section{Meal planning}

Low income means not only limitations in travel and trip expenses. Calculating within financial restraint is strongly emphasized also in the context of meal management. Generally, it can be observed that the interviewees apply various methods of rational management of available resources: If I have chicken stock on Sunday, then I make tomato soup on Monday (laughing) (K/2). The respondents are usually planning food expenses for the next week: I was brought up in that way that everything has to be planned in advance (...), I don't want to cook only for myself, meat only on Sunday or when my grandchildren come $(\mathrm{K} / 21)$. Effective management of resources, despite its positive impact on household budget, does not always allow to compose balanced meals and diet.

A common practice is buying in the discount stores, looking for products on special offers or buying them during sales. Such actions mean that the interviewees, making consumer choices, mainly care about the price, not the quality of goods and principle of proper combining of food products. Therefore, their diet does not fully meet the demands of their bodies. The senior citizens realise that, but do not believe that it can change. You know, what can I say, I'd like it to be different (...) my daughter always says that to me (...), but how can I do it, I don't have enough money $(\mathrm{K} / 21)$.

\section{Recycling and rational economy}

Cuts and economy emerge also with reference to the elements of interior furnishings, as well as hygienic articles and cleaning supplies. The interviewees also avoid unnecessary purchases of new clothes, saying that the ones they have are of good quality and can still be used. There is a principle that until specific product is good to use, there is no need to replace it with a new one. One significant issue is strongly emphasized in the interviewees' statements. It is widely believed that there is a high correlation between earlier experiences (occurrence of crisis moments in a trajectory of life) and ability to deal with current problems. One may have the impression that most of the interviewees have developed an ability to manage the available resources, which allows them to rationally manage their capital.

\section{Support networks}

Using internal resources is not always sufficient. Financial problems often force to look for help beyond one's own household. An analysis of collected research material shows that in such cases, the seniors are supported by their relatives: My husband's pension is not too high, but life goes on, my daughter sometimes helps me financially, my son-inlaw buys me drugs (...) and life goes on (...) (K/11). However, it should be emphasized that the respondents treat it as a last resort. The respondents think that their families (children) have their own needs, expenses and asking them for help can be too much of a burden: You know, I don't want to bother my daughters (...), they have their own children 
and expenses $(\ldots)(\mathrm{K} / 2)$. The sense of shame, maybe even humiliation also emerges: I don't want to ask them for help (...), I want to handle things myself (M/1). It is much easier for the interviewees to accept help in the form of products/drugs/firewood, and not money.

The seniors also make use of various benefits; apart from obvious ones (retirement pension, life pension), they are usually allowances (e.g., nursing allowance). The concessions (e.g., for means of public transport) or exemptions (e.g., from subscription fee) are widely used. The interviewees are quite well-informed good about their rights (for example, they make use of a designated benefit for the purchase of firewood), but - as they admit - there are no clear rules of granting specific benefits, and no help, for example, in filling in application forms. They treat assessment of the actions of local authorities with reserve. On the one hand, they appreciate financial support, on the other hand, they think that they are "left alone" and they would need more organized care in everyday activities. Negative comments also emerge with reference to housing policy. The lack of renovations, repairs, delays in, for example, insulation of flats cause frustration and the sense of ignoring their needs. One of the interviewees said that: Nobody cares about us. I was asking, calling so many times, but when they say that something would be done, they don't do it $(\mathrm{K} / 3)$. The senior citizens complain not only about technical condition of their own households, but also about the actions of authorities concerning the whole infrastructure and its environment. The actions connected with keeping squares and staircases/courtyards clean are assessed particularly negative. The interviewees admit that it does not affect their resources, but has significant impact on their comfort of life. It can also be observed that there are no organized actions aiming at raising awareness of consequences resulting from potential/ real fuel poverty. The interviewees do not have sufficient knowledge of how to prevent fuel poverty and how to deal with its potential effects.

Poor knowledge of the subject and the existing threats emerges in another issue that we raised. Health problems are very rarely, not to say - marginally - connected with fuel poverty of the respondents. It is astonishing because data (IBS, 2019) show strong correlation between fuel poverty and diseases (respiratory diseases: asthma, bronchitis, pneumonia, etc.). It has a negative impact on people's mental health; economic problems, including those connected to the low temperature in the rooms or dampness, cause low mental condition, depression, anxiety disorder, and then social marginalization and exclusion. However, the interviewees seem not to see thes relations and connect discomfort rather to their old age, and not with consequences of fuel poverty. Based on the interviewees' statements, it can be concluded that they rather blame town/district (district of "deportation") for poor conditions of their households, and they think that it "can't be changed" and will remain a permanent element of their residential tissue.

\section{Discussion and recommendations}

The connection between fuel poverty and fulfilment of other consumer needs by the elderly was outlined in the article. The main causes of fuel poverty and the most important consequences of energy difficulties were determined. There were also attempts to indicate 
the fields of action for local authorities that can and should intensify the works on the programs focused preventing fuel poverty.

The study which was the basis of this article allowed us to formulate the following conclusions: fuel poverty is a real threat for the elderly. Old, energetically inefficient residential buildings, of the growing energy and gas bills in combination with limited (retirement pension, life pension) resources are the most significant factors responsible for dynamics of development of fuel poverty. The lack of knowledge, consciousness, and practical instructions on how to deal with this problem often leads to negative consequences, including concessions in managing a household budget. In the first place, nutritional practices are changed; the respondents choose the cheapest food on the food market, trying to rationally manage their resources. The issues of balancing healthy meals or introduction of a proper diet are receded into the background. The limitations or "cost cuts" also affects wearing and buying clothes, interior design, or management of free time. The respondents "don't spend money on their own needs" as a remedy for financial problems and method of "patching up gaps" in the budget. The respondents resign from recreational trips and holidays, replacing them with family visits, walks in the neighbourhood or meetings with friends. These practices generally confirm the basic assumptions concerning fuel poverty saying that in the situation that the costs of satisfaction of energy needs are too high, it is necessary to economise at the expense of other consumer goods or limit the needs (Asist, 2020). The scale of these actions is certainly surprising and also alarming; the research showed that seniors reconstruct of the majority of the practiced patterns of consumer behaviours. The interviewees do not identify a problem of fuel poverty as a separate problem. They treat is as a consequence of high energy prices and low income, as well as an effect of ineffective housing and renovation policy. Fuel poverty is not connected with irrational use of energy. The senior citizens emphasize that energy bills eat up large part of their budgets. The methods implemented by them are practically reduced only to saving energy (turning off the light, TV set); there are no more resolute actions, for example, replacing the light bulbs or domestic appliances with energy efficient ones. It is generally believed that such actions are long-term investment that seniors cannot (or do not want) to wait for.

What is more, it is widely believed that "nothing can be done" with the problem. The senior citizens seem to be convinced that the situation cannot be any different. Such attitude demonstrates a low level of trust and the lack of belief of the interviewees that national policies and instruments that directly and indirectly tackle people affected by fuel poverty may be effective.

A method of dealing with the situation is saving (not only energy) and using ecologically ineffective heating sources. Emerging fuel problems motivate the senior citizens to look for help in appropriate institutional units, however, it is hard, based on collected opinions, to assess the effectiveness of actions taken by the commune. Further monitoring of their work seems to be crucial. It is also necessary to develop proper methods of execution of taken obligations, based on the idea of combining instruments of social, energy, housing, and environmental policies. 
The lack of knowledge, information about causes and consequences of fuel poverty, as well as information of how to prevent the phenomenon can be observed. The need to shape behaviours and educate within the scope of effective use of energy in the households, although signalled many times (Miazga \& Owczarek, 2015), is particularly important in the context of the elderly. Information campaigns or educational programs in mass media seem to be far from satisfactory, and also not too effective. Local government - commune or district - and institutions involved in continuing education of the senior citizens should play an important role here. The statements of the interviewees showed that counteracting the effects of fuel poverty is very rarely or rather not at all the subject of meetings or conversations.

Although respondents suffer from various diseases, they sporadically connect them with fuel poverty. This attitude, although alarming, is common: "Vulnerable consumers are often prepared to compromise their energy comfort and expose themselves to health risks in order to cut their energy expenses. A widespread practice of underheating to reduce energy bills has been observed. Therefore, special attention needs to be taken to ensure that households do not curtail their energy use in a way that would jeopardise their health or well-being" (Hajdinjak \& Asenova, 2019).

The conducted study certainly does not deal with all aspects of the subject; however, it can be a starting point to conduct similar research in different regions of Poland. Conducting research on fuel poverty is an opportunity to integrate the dispersed research communities dealing with the concept of determination of macroeconomic and microeconomic, as well as social connections leading to fuel poverty, especially in socially sensitive groups. Identification of the problem shows the occurrence of strong correlations between situation observed in Silesian province and different regions of the countries of Eastern Europe. The causes and consequences of fuel poverty among the elderly determined in the research give an opportunity to arouse interest in energy restructuring of economy and society of the region, which must be connected with activity of scientific communities, taking into account and supporting regional point of view not only in the context of restructuring of industry, but also the whole, broadly understood economy and policy of the region. Putting emphasis on interdisciplinary character of the phenomenon is particularly important: "Various stakeholders from complementary fields need to cooperate, learn from one another, and create new strategies to tackle the problem" (Ecoserveis Association, 2018).

\section{References}

Aron, C., Kostrzewa, J., Owczarek, D., Świdrowska, E. (2013). Poland: Making energy efficiency investments vailable to the poor. Raport wewnętrzny Banku Światowego, Waszyngton.

Assist (2020). Ubóstwo energetyczne w Polsce. Konsumenci wrażliwi i ubóstwo energetyczne, KAPE, http://www.federacja-konsumentow.org.pl/225, assist--siec-doradcowwrazliwych-odbiorcow-energii.html. 
Boguszewski, R., Herudziński, T. (2018). Ubóstwo energetyczne w Polsce. Pracownia Badań Społecznych SGGW.

Bouzarovski, S. (2011). Energy Poverty in the EU: A Review of the Evidence. Luettavissa.

Bouzarovski, S., Petrova, S. (2015). A global perspective on domestic energy - deprivation: overcoming the energy poverty-fuel poverty binary. Energy Research \& Social Science, 10.

CAN, LIFE Unify (2020). Tackling energy poverty through National Energy and Climate Plans: Priority or empty promise?, https://caneurope.org/tackling-energy-povertythrough-national-energy-and-climate-plans-priority-or-empty-promise/.

Day, R., Hitchings, R. (2009). Older People and their Winter Warmth Behaviours: Understanding the Contextual Dynamics. School of Geography, University of Birmingham / Dept Geography, UCL.

Dénes F., Orsolya, F. (2012). Poverty or Fuel Poverty? Defining fuel poverty in Europe and Hungary. Executive Summary.

Diagnoza Problemów Społecznych (2014). http://www.swietochlowice.pl/dokumenty-strategiczne.html.

Ecoserveis Association (2018). Atlas of Initiatives of Energy Poverty in Europe. Stateby-state Review.

EPEE project (2009). Tackling Fuel Poverty. Recommendation Guide for Policy Makers; Detailed report on the different types of existing mechanisms to tackle fuel poverty, WP3-Deliverable 8, www.fuel-poverty.com.

EPOV (2020). Member state reports on energy poverty 2019, https://op.europa.eu/en/ publication-detail/-/publication/b9a25ba4-9ef6-11ea-9d2d-01aa75ed71a1/language-en.

European Union (2018). Directive (EU) 2018/2002 of the European Parliament and of the Council of 11 December 2018 amending Directive 2012/27/EU on energy efficiency (Energy Efficiency Directive 2018/2002) https://eur-lex.europa.eu/legal-content/EN/ $\mathrm{TXT} / \mathrm{PDF} /$ ?uri=CELEX:32018L2002\&from $=\mathrm{EN}$.

European Union (2018). Directive (EU) 2018/844 of the European Parliament and of the Council of 30 May 2018 amending Directive 2010/31/EU on the energy performance of buildings and Directive 2012/27/EU on energy efficiency (Energy Performance in Buildings Directive 2018/844), https://eur-lex.europa.eu/legal-content/EN/TXT/PDF/ ?uri $=$ CELEX:32018L0844\&from $=$ EN.

Eurostat (2018). https://ec.europa.eu/social/main.jsp?catId=860\&langId=pl.

Frankowski, J. (2020). Attention: Smog Alert! Citizen Engagement for Clean Air and Its Consequences for Fuel Poverty in Poland. Energy and Buildings.

GUS (2018). Gospodarka mieszkaniowa w latach 2013-2017, https://stat.gov.pl/obszarytematyczne/infrastruktura-komunalna-nieruchomosci/nieruchomosci-budynki-infrastruktura-komunalna/gospodarka-mieszkaniowa-w-latach-2013-2017,11,1.html.

GUS (2020). Gospodarka mieszkaniowa i infrastruktura komunalna w 2019 r., https://stat. gov.pl/obszary-tematyczne/infrastruktura-komunalna-nieruchomosci/.

Hajdinjak, M. \& Asenova, D. (2019). Sustainable Energy Consumption and Energy Poverty: Challenges and Trends in Bulgaria. 
Hills, J. (2012). Getting the measure of fuel poverty. Final report of the fuel poverty review, CASE report no. 72, commissioned by the Department of Energy and Climate Change (DECC) of the United Kingdom. London.

Househam, I. \& Musatescu, V. (2012). Improving Energy Efficiency in Low-Income Households and Communities in Romania: Fuel Poverty Draft assessment report. http://isap.sejm.gov.pl/isap.nsf/DocDetails.xsp?id=WDU20170001769.

http://www.ure.gov.pl/portal/pl/538/2668/Europejska_Karta_Praw_Odbiorcow_Energii. html.

IBS (2019). Ubóstwo energetyczne a zdrowie, https://ibs.org.pl/research/ubostwo-energetyczne-a-zdrowie/.

IBS (2/2018). Zjawisko ubóstwa energetycznego w Polsce, $w$ tym ze szczególnym uwzględnieniem zamieszkujacych $w$ domach jednorodzinnych, https://ibs.org.pl/publications/ zjawisko-ubostwa-energetycznego-w-polsce-w-tym-ze-szczegolnym-uwzglednieniemzamieszkujacych-w-domach-jednorodzinnych/.

IBS (2018). Ubóstwo energetyczne $w$ Polsce 2012-2016. Zmiany $w$ czasie $i$ charakterystyka zjawiska, http://obserwatorium.miasta.pl/wpcontent/uploads/2018/02/IBS_Brief_ Report_Ub\%C3\%B3stwo_energetyczne_w_Polsce_2012-2016.pdf.

Jiglau, G. (2020). Energy poverty as a threat to democracy in post-communist countries, Perspectives on Energy Poverty in Post-Communist Europe, Routledge.

Karásek, J. \& Pojar, J. (2018). Programme to reduce energy poverty in the Czech Republic, Publishing Info.

Khandker, S. (2013). Why energy poverty may differ from income poverty. In Let's talk development, https://blogs.worldbank.org/developmenttalk/why-energy-poverty-maydiffer-income-poverty.

Krajowy Program Przeciwdziałania Ubóstwu i Wykluczeniu Społecznego 2020. Nowy Wymiar Aktywnej Integracji, https:/www.gov.pl/web/rodzina/bip-krajowy-programprzeciwdzialania-ubostwu-i-wykluczeniu-spolecznemu-2020-nowy-wymiar-aktywnejintegracji.

Kuhar, M. (2020). In CAN, LIFE Unify (2020). Tackling energy poverty through National Energy and Climate Plans: Priority or empty promise?, https://caneurope.org/tacklingenergy-poverty-through-national-energy-and-climate-plans-priority-or-empty-promise/.

Kulinska, E. (2017). Defining Energy Poverty in Implementing Energy Efficiency Policy in Bulgaria. pec.org/a/nwe/eajour/y2017i4p671-684.html

Kurowski, P. (2008). Wydatki gospodarstw domowych na energię elektryczną. Próba ustalenia grup odbiorców wrażliwych na podwyżki cen energii (wyniki na podstawie badań GUS z 2006 r.). Biuletyn URE, 5.

Kwon J. H., Jang, M. (2017). Housing quality, health and fuel poverty among U.S. seniors in: Sage Journals, https://journals.sagepub.com/doi/10.1177/1420326X17710807.

Kyprianou, I., Serghides, D., Varo, A., Gouveia, J. P., Kopeva, D., Murauskaite, L. (2019). Energy Poverty Policies and Measures in 5 EU Countries: A Comparative Study. 
https://sites.fct.unl.pt/times-pt/publications/energy-poverty-policies-and-measures-5eu-countries-comparative-study

Lampietti, J. \& Meyer, A. (2002). Coping with the Cold: Heating Strategies for Eastern Europe and Central Asia's Urban Poor. https://openknowledge.worldbank.org/ handle/10986/15174

Latvian, Government (2018). Draft National Energy and Climate Plan of Latvia 2021-2030.

Lenz, N. V. \& Grgurev, I. (2017). Assessment of Energy Poverty in New European Union Member States: The Case of Bulgaria, Croatia and Romania. https://www.econjournals.com/index.php/ijeep/article/view/4003

Liddell, C. \& Guiney, C. (2015). Living in a cold and damp Home: Framework for understanding impacts on mental well-being. Public Health, 129.

Lis, M., Ramsza, M., Miazga, A. (2015). Dynamiczne własności miar ubóstwa energetycznego. Instytut Badań Strukturalnych, Warszawa, http://ibs.org.pl/publications/dynamiczne-wlasnosci-miar-ubostwa-energetycznego/.

Miazga, A. \& Owczarek, D. (2015). Dom zimny, dom ciemny, czyli ubóstwo energetyczne w Polsce. Instytut Badań Strukturalnych, Warszawa, http://ibs.org.pl/publications/ domzimny-dom-ciemny-czyli-ubostwo-energetyczne-w-polsce/.

Middlemiss, L. (2019). Energy poverty and social relations: A capabilities approach. Energy Research \& Social Science, 55. https://www.sciencedirect.com/science/article/ pii/S2214629618310004

Middlemiss, L. \& Gillard, R. (2015). Fuel poverty from the bottom-up: characterising household energy vulnerability through the live experience of the fuel poor. Energy Research\& Social Science, 6.

ONZ (2018). Global Age Watch Insights 2018: Report, summary and country profiles, http:// globalagewatch.org/global-agewatch/reports/global-agewatch-insights-2018-reportsummary-and-country-profiles/.

Papada, L. \& Kaliampakos, D. (2018). A Stochastic Model for energy poverty analysis. Energy Policy, 116.

Pollard, A., Jones, T., Sherratt, S., Sharpe, R. A. (2019). Use of Simple Telemetry to Reduce the Health Impacts of Fuel Poverty and Living in Cold Homes. International Journal of Environmental Research and Public Health, 16(16), 2853, https://doi. org/10.3390/ijerph16162853.

Pyka, M., Liszka, S., Czajkowski, J., Kukla, M. (2014). Ubóstwo energetyczne. Wyniki badania ankietowego oraz propozycje dotyczace pomocy osobom ubogim energetycznie, Instytut na rzecz Ekorozwoju, Fundacja na rzecz Efektywnego Wykorzystania Energii. Katowice-Warszawa http://www.chronmyklimat.pl/biblioteka/ksiazki-raporty/ubostwoenergetyczne-wyniki-badania-ankietowego-oraz-propozycje-dotyczace-pomocyosobomubogim-energetycznie.

ROPS: https://rops-katowice.pl/wp-content/uploads/2019/04/2019.04.12Informacja-o-wynikach-bada\%C5\%84-WSG-za-2019.pdf. 
Rutkowski, J., Sałach, K., Ziółkowska, K., Szpor, A. (2018). Jak ograniczyć skalę ubóstwa energetycznego w Polsce?, Instytut Badań Strukturalnych http://ibs.org.pl/publications/ jakograniczyc-skale-ubostwa-energetycznego-w-polsce/.

Sałach, K. \& Lewandowski, P. (2018). Ubóstwo energetyczne w Polsce 2012-2014. Instytut Badań Strukturalnych.

Scarpellini, S., Sanz Hernández, M. A., Moneva, J. M., Portillo-Tarragona, P., Schleich, J. (2019). Energy efficient technology adoption in low-income - households in the European Union - What is the evidence?, Energy Policy, 125.

Sokołowski, J., Lewandowski, P., Kiełczewska, A., Bouzarovski, S. (2019). Measuring energy poverty in Poland with the multidimensional energy poverty index. Instytut Badan Strukturalnych.

Staniszewska, M. (2018). Ubóstwo energetyczne jako problem społeczny i sposoby jego rozwiązywania. Wrocławskie Studia Politologiczne, 25.

Strakova, D. (2015). Energy Poverty in Slovakia. https://www.researchgate.net/publication/275580010_Energy_Poverty_in_Slovakia.

Strategia Rozwoju Świętochłowic do roku 2030, http://www.swietochlowice.pl/dokumentystrategiczne.html.

Strategia Rozwoju Województwa Śląskiego "Śląskie 2020+".

Strategia Rozwoju Województwa Śląskiego "Śląskie 2020+" Uchwała Sejmiku Województwa Śląskiego Nr IV/38/2/2013 z dnia 1 lipca 2013 r.

Strategia Rozwoju Województwa Śląskiego "Śląskie 2030”, https://rcas.slaskie.pl/.

Świętochłowice-Lipiny, http://slaskiemiasta.pl/swietochlowice/lipiny

The UK Fuel Poverty Strategy. 6th Annual Progress Report 2008, Defra i BEER.

Thomson, H., Snell, C., Bouzarovski, S. (2017). Health, Well-Being and Energy Poverty in Europe: A Comparative Study of 32 European Countries. International Journal of Environmental Research and Public Health, 14(6).

Tirado Herrero, S. \& Ürge-Vorsatz, D. (2010). Fuel Poverty in Hungary: A first assessment. http://archive.ceu.hu/sites/default/files/field_attachment/project/node-3347/englishreportfuelpoverty.pdf

Ustawa z dnia 12 marca 2004 r. o pomocy społecznej, Dz.U. 2017 poz. 1769.

Walker, M. (2004). Marketing to seniors. 1st Book Library.

Węglarz, A., Kubalski, G., Owczarek, D. (2014). Propozycje mechanizmów wsparcia procesu przeciwdziałania zjawisku ubóstwa energetycznego w Polsce. Instytut na Rzecz Ekorozwoju, http://www.ineisd.org.pl/theme/UploadFiles/File/publikacje/broszury/broszura_ ine_ubostwo_www.pdf.

Wódz, K. \& Szpoczek-Sało, M. (2016). Świętochłowickie Lipiny — enklawa biedy czy “miejska wioska”? In K. Wódz, G. Libor, D. Nowalska-Kapuścik, Peryferie społeczne $w$ teorii i badaniach empirycznych. Wydawnictwo UŚ.

Živčić, L. \& Tkalec, T. (2014). Report on national situation in the field of energy poverty - Slovenia. https://www.energypoverty.eu/publication/report-national-situation-fieldenergy-poverty-slovenia. 